and pioneered in Central Europe 150 years ago. In Europe and Asia, where the older generation tends to view any popularization of science as suspicious and unnecessary, forensic entomology was kept alive after the war by only four scientists. Such historical details are only briefly mentioned by Goff. For the same reason, the use of non-metric units and Americanized species

names, such as

Phaenicia

instead

of Lucilia,

is understandable.

However,

the contributions

of Russian, Belgian, French,

Finnish, Canadian and German

researchers should not be underestimated. Therefore, and to get additional perspectives into forensic entomology, I would recommend three further recent publications. One is a special issue of the journal Forensic Science International on the subject (of which I am the guest editor), which will also include the latest research results to be presented at an international meeting of forensic entomologists held in Brazil in August 2000 (http:// www.benecke.com/feauthor.html). There is also a well-researched popular-science book by Jessica Snyder-Sachs about to be published, and the scientific handbook Entomological Evidence: The Utility of Arthropods in Legal Investigations (CRC Press, 2000). Meanwhile, enjoy Goff's beautifully illustrated, scientifically sound and entertaining story. Mark Benecke is in the Forensic Biology Research Unit, Institute for Zoology, University of Cologne, Cologne 50923, Germany.

\title{
Of viruses and men
}

\section{Virus: The Co-discoverer of HIV Tracks its Rampage and Charts the Future \\ by Luc Montagnier \\ W. W. Norton: 1999. 256 pp. \$24.95, £18.95}

\section{Robin A. Weiss}

The book telling the story of AIDS should be a thriller. The explosion of a deadly novel disease involving sex and drugs, its origins and the ensuing pandemic, the unfolding epic of finding its cause, the rivalry involved, the rapid development of science-based diagnosis and later treatment, how Western gays empowered patients, the hapless scene in Africa - all these facets could make gripping reading. We await an inspired writer to take up the challenge.

When Bob Gallo's Virus Hunting (Basic Books, 1991) was published, Mirko Grmek, the author of History of AIDS (Princeton University Press, 1993) who sadly died on 6 March, remarked that "Generals write memoirs; history is best left to historians". In the battle for credit for the discovery of HIV, the general leading the French troops followed with his own memoirs, Des Virus et des Hommes (Odile Jacob, 1994), now updated and translated under the title Virus. Luc Montagnier's book comprises a brief account of his career, the discovery of HIV, and chapters dealing in lay terms with HIV and AIDS as a global problem.

While Montagnier's experiences as a young scientist in Britain are told with wry humour, most readers will zoom in on his account of the race to isolate and characterize HIV. This is by far the most interesting section of the book, whereas the second half, about the understanding, treatment and proposed prevention of HIV infection, seems rather mundane.

Unlike contemporaneous diaries, memoirs benefit from hindsight. Naturally, the author of Virus portrays himself in a favourable light, although he is no more selfserving than one reviewer of his book. Besides, although the French were treated shabbily over the discovery of HIV, Montagnier won this battle, as the record of research papers makes clear.

The Institut Pasteur team published their preliminary observations on a new human retrovirus linked to AIDS in Science in May 1983, and by April 1984 had published further papers on new isolates from AIDS patients and had found that HIV was more closely related to animal lentiviruses (by its morphology and cell-damaging effect) than to the human T-cell leukaemia viruses (HTLVs). The American team first presented their evidence for an AIDS virus in May 1984 and throughout that year maintained that it was related to the HTLVs. When the gene sequences were published in January 1985 (Nature, Montagnier notes, declined to consider the French paper), it became apparent how distinct HIV was. And when a West African man in Portugal developed AIDS without evidence of HIV-1 infection, Montagnier's group identified the second AIDS virus, HIV-2.

For a victorious general renowned throughout the world, Montagnier remains surprisingly bitter. He portrays himself as a prescient though misunderstood scientist who, almost alone, saw the danger of the AIDS agent contaminating the blood supply but was ignored. He complains that a plea to expand his laboratory went initially unheeded by the Institut Pasteur, believing that extra funds should have flowed automatically from his letter - perhaps he has never needed to write a proper research grant application. He feels that his theory that progression from HIV infection to AIDS requires an essential cofactor to

\section{New in paperback}

\section{Eco-pragmatism: Making Sensible \\ Environmental Decisions in an Uncertain World}

by Daniel A. Farber

University of Chicago Press, $\$ 15, £ 10.50$

"Daniel Farber's is a timely and well-argued contribution to the understanding of how judicial systems can maintain the balance between competing environmental and economical claims. It does more than that: it puts forward a framework for using judicial pragmatism to integrate environmental considerations into economic activities." Calestous Juma, Nature 399, 653-654 (1999)

The Descent of Mind: Psychological Perspectives on Hominid Evolution edited by Michael C. Corballis \& Stephen E. G. Lea

Oxford University Press, $£ 17.99$

\section{Green Chemistry: Theory and Practice}

by Paul T. Anastas \& John C. Warner University of Chicago Press, $\$ 25, £ 17.50$ “... as Anastas and Warner point out in Green Chemistry: Theory and Practice, synthetic chemists have not been particularly environmentally conscious... The book defines the 12 principles of green chemistry - described as the Hippocratic oath for chemists... Anastas and Warner's prediction of future trends is a mixed bag of well-defined goals." Roger Sheldon, Nature 399, 33 (1999)

\section{Intellectual Impostures}

by Alan Sokal \& Jean Bricmont Profile Books, £6.99

The Nature of the Book: Print and Knowledge in the Making

by Adrian Johns

University of Chicago Press, \$22.50, £16

"The publication of science books, as much as any kind of book, is a complex process, involving a range of parties and interests, not all with common aims. It is basically this insight, applied to the burgeoning scientific culture of seventeenth-century England, that underlies Adrian Johns's provocative and stimulating, if ultimately not wholly satisfactory, book." Michael Hunter, Nature 396, 534-536 (1998)

Virtual Organisms: The Startling World of Artificial Life

by Mark Ward

Pan, $£ 6.99$

The Great Disruption: Human Nature and the Reconstitution of Social Order by Francis Fukuyama

Profile Books, £8.99 
HIV met too cool a response from the scientific community, although he has softened his fixation on Mycoplasma as the essential cofactor in this new English edition.

Montagnier depicts his style of leadership as authoritarian rather than persuasive. $\mathrm{He}$ "instructs" fellow scientist Jean-Claude Chermann to set up serological assays, and he "assigned to Marc Alizon the arduous task of cloning" HIV, to be sequenced with Simon Wain-Hobson and Pierre Sonigo. I think Montagnier does himself injustice here, for, by the time I arrived on sabbatical at the Bâtiment du SIDA, the pasteuriens were living up to Emile Roux's ideal "where individuals could contribute to a common goal without risking their intellectual freedom". But by then, Chermann had left for a sunnier clime, while Alizon and Sonigo had moved to the Institut Cochin.

Montagnier claims he gained his insight into AIDS because he trained in medicine as well as science. "Clinicians take care of the sick. Researchers take care of lab work. And most importantly, no one can stray from his or her corner. I have taken the risk of transgressing these customs." But after a generation of $\mathrm{MD} / \mathrm{PhD}$ programmes, Montagnier is by no means unique. He wrongly states that "Gallo was not a medical doctor, but rather a biochemist by training", and that this led Gallo to "misunderstandings and blunders". This general does not know his adversary.

In the epilogue, Montagnier explains how he is using his fame to fight the real enemy, AIDS. "I have realised that my position as a pioneer researcher and the notoriety I have achieved should help me to reach beyond my research activities and contribute to resolving the problem of AIDS worldwide." Accordingly, he set about establishing three centres, in a private hospital in Paris, in Abidjan on the Ivory Coast, and at Queens College, New York, with further centres promised across the world. Alas, not long after writing of this grandiose enterprise, more bitter pills are having to be swallowed as the New York and Paris schemes collapse. As with biotechnology companies, pioneers do not always make the best chief executive officers.

Overall, the book is illuminating not so much about AIDS as about the attitudes and vicissitudes of one of its major players. Now that the two opposing generals have set down their memoirs, the troops will hope they can march forward peacefully towards better treatment and an effective vaccine. There is, however, one further memoir I should like to read but doubt will be written - that of Françoise Barré-Sinoussi, the Rosalind Franklin of HIV.

Robin A. Weiss is at the Windeyer Institute, University College London, 46 Cleveland Street, London W1P 6DB, UK.

\section{Science in culture}

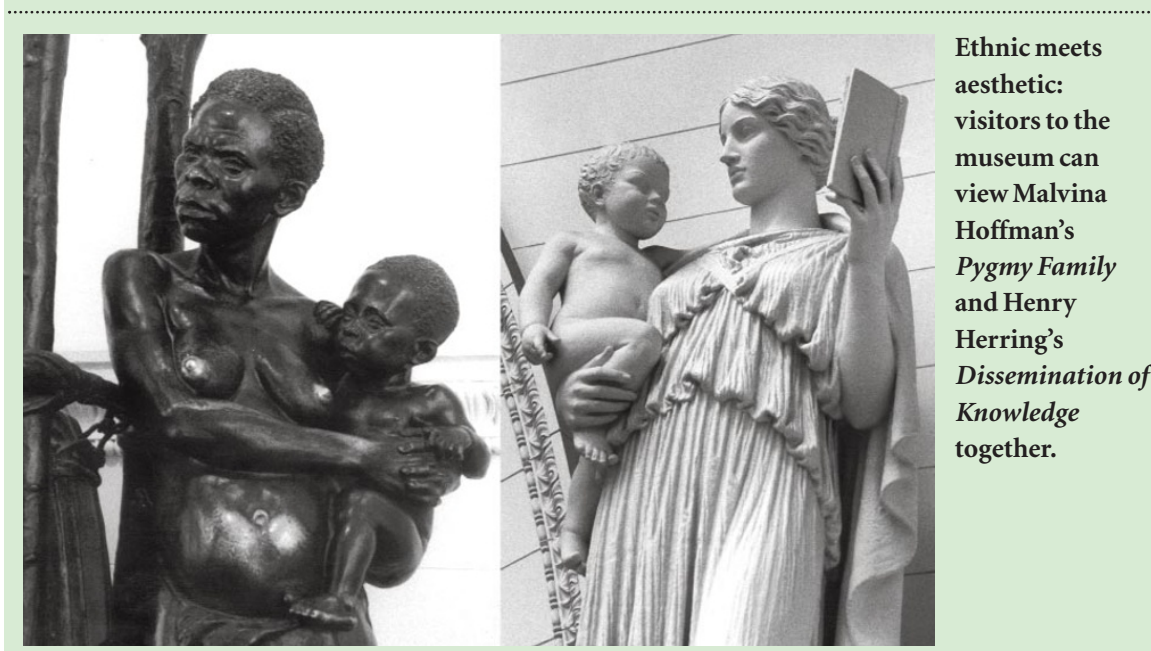

\section{Type and archetype}

Hoffman and Herring in the Field Museum, Chicago.

Martin Kemp

The Field Museum in Chicago, built to house the biological and anthropological collections for the World's Columbian Exposition in 1893, is one of those remarkable foundations in which the creations of nature and 'artistic masterpieces' stand cheek-by-jowl as much by accident as by design. Devoted to natural history and anthropology, those fraternal twins of nineteenth-century science, the museum contains a rich treasury of artefacts originally collected from exotic cultures as items of ethnographic significance. Many, such as African masks and oriental jade, would now seem equally at home as aesthetic treasures in the nearby Art Institute.

A few works were ordered specifically from contemporary artists as a more conscious effort to bring 'art' into the museum. In 1930, the notable sculptor Malvina Hoffman was commissioned to create a series of bronzes of ethnic types from around the world. The commission had a distinguished, mainly French ancestry, most notably the striking ethnic busts by CharlesHenri-Joseph Cordier assembled from 1851 onwards in the anthropological gallery of the Muséum National d'Histoire Naturelle.

Born in New York in 1885 and trained by the great Auguste Rodin in Paris, Hoffman had gained a reputation for strongly characterized portraits and family groups. For the Field project she produced not only busts but also life-size figures, often in action, and ingeniously staged groups. The Pygmy Family from the Ituri Forest in northeast Congo, sculpted in 1931, gives a good idea of the powerful modelling and vivid portrayals characteristic of the 104 works that more than adequately met the museum's expectations.

Almost three-quarters of a century later, the conceptual framework within which we approach the works has become more complex. No longer displayed in the Hall of the Races of Mankind, they are now dispersed in perambulatory spaces.
The 'politically correct' curator of today is likely to feel a tinge of unease in the face of such picturesque portrayals of exotic racial types as objects of artistic curiosity. Immediately at the top of the stairs, a display featuring busts of a Zulu and a Padang woman (the latter's neck extended by stacked rings) accordingly invites us to consider the cultural construction of beauty. Photographs of Elisabeth Vigée-Lebrun's elegant portrait of Marie Antoinette, Rubens' voluptuous Feast of Venus and bikini-clad sunbathers on a Californian beach aspire to render Western conventions as curious as the strange customs of African 'natives'.

The museum's free brochure-map seems to signal unease when it exhorts each visitor to the "Exhibitions about Culture" to consider how "some of these exhibits may portray people or ideas that are new to you. Thank you for viewing all the displays with respect for the traditions and environments they represent."

One potentially telling element in the museum's visual ensemble of artistry is now more likely to be overlooked than treated with active disrespect. In the main hall, high above Carl Akeley's compelling taxidermic drama of two elephants fighting, stand two immaculately white statues representing Science and The Dissemination of Knowledge, commissioned from Henry Herring in 1915. Standing on the balcony, we can stare directly across from the lumpily uncompromising portrayal of the bronze woman and child in Hoffman's Pygmy Family to the Grecian perfection of Herring's high-minded allegory.

As with so much anthropological characterization, the aesthetic ideal set by ancient marble Venuses and the Apollo Belvedere continued to provide the ingrained visual filters through which other works were evaluated. Ethnic type stood characterized by contrast to aesthetic archetype. Is this a habit we have wholly discarded?

Martin Kemp is in the Department of the History of Art, University of Oxford, 35 Beaumont Street, Oxford OX1 2PG, UK. 